\title{
5
}

\section{Guided by her: Aboriginal women's participation in Australian expeditions}

\author{
Allison Cadzow
}

I was compelled in a great measure to be guided by her. She was acquainted with all their haunts and was a native of Port Davey, belonging to this tribe and having a brother and other relatives living among them, [Low. Ger Nown] was her native place. Though I knew she intended sojourning with them, yet there was no alternative but to follow her suggestions ...

George Augustus Robinson discussing Dray's guiding in Tasmania (6 April 1830)

Our female guide, who had scarcely before ventured to look up, stood now boldly forward, and addressed the strange tribe in a very animated and apparently eloquent manner; and when her countenance was thus lighted up, displaying fine teeth, and great earnestness of manner, I was delighted to perceive what soul the woman possessed, and could not but consider our party fortunate in having met with such an interpreter.

Thomas Mitchell discussing Turandurey's guiding in New South Wales (12 May 1836)

The Aboriginal women mentioned above are clearly represented as guides and appear in plain view; they are not in hiding. While women did hide from white expedition members - for good reason considering 
the frequent violence of white people towards them - this was not the only reaction they had. Historians have largely ignored Aboriginal women's involvement in exploration expeditions, though there are some notable exceptions in the work of Henry Reynolds, Lyndall Ryan and Donald Baker. Some other authors who have attended to them, such as Philip Clarke, imply that women were invariably hidden away during encounters, suggesting they were not actively involved in expeditions. ${ }^{1}$ Even when women did hide, this was not necessarily the end of the story, as they sometimes re-emerged after assessing the situation. Some women reputedly approached expedition members, aware that they were a group of men without white women present, as the accounts of Charles Sturt, Daniel Brock and Thomas Mitchell show, though such comments from expedition participants need careful consideration. ${ }^{2}$ Other women, like Dray of Tasmania and Turandurey in New South Wales as shown above, acted as guides and interpreters.

This chapter will argue that while it is vital to maintain awareness of accounts of women in hiding, we also need to look at representations of women's involvement in expeditions and to consider their contributions, motivations and interests in guiding explorers through country. The chapter will briefly discuss historiographical material on women's agency in expeditions and how women's presence in exploration journals has been obscured or ignored in histories of exploration. It then focuses on close reading of two major expedition accounts, rather than trying to cover a full range of Aboriginal women's participation in expeditions. By bringing together examples that tend to be discussed separately, it is possible to see connections across different expeditions and to begin to interpret the women's actions in their own social and cultural contexts. The accounts of missionary George Robinson's Tasmanian Port Davey expedition of 1830 with Dray, Trugananner, Pagerly and others (one of six expeditions), and NSW Surveyor General Thomas Mitchell's 1836 expedition in New South Wales and Victoria where Kitty and Turandurey guided are examined.

1 Clarke 2008: 22.

2 See, for example, Tcherkézoff's (2009) cautionary discussion of representations of Polynesian women giving themselves 'freely' to the expeditioners. Brock 1975: 45, 135; Sturt 1965 [1849]: 295-296. See also Thomas Mitchell cited in Baker 1997: 65-66. Daniel Brock, bird collector and gunsmith on Sturt's inland expedition of 1844, noted that Nitebook, their Aboriginal guide, teased him about his wife Delia's absence. He hid behind bushes and called out 'Brock Lubra Delia', to surprise Brock. Brock 1975: 41. 
These examples offer opportunities to consider how women were involved in expeditions, the skills they demonstrated and a chance to read their actions and statements for signs of their motivations and perspectives.

\section{Historians and women guides}

Henry Reynolds has included brief coverage of women such as Toodyep in Western Australia within accounts of Aboriginal intermediaries and their involvement in expeditions. In other publications, he has also considered Trugannaner and Dray's political role in Robinson's expedition (discussed further later in this chapter) and the importance of their cultural and language skills to the expedition's progress. ${ }^{3}$ Lyndall Ryan has closely examined George Robinson's expeditions in Tasmania and the involvement of Trugananner, Dray and others in her histories of Aboriginal Tasmania, ${ }^{4}$ while Donald Baker has discussed the work of specific women guides within an examination of Thomas Mitchell's relations with Aboriginal people and expeditions. ${ }^{5}$ These works, however, are not primarily focused on Aboriginal women and exploration, nor do they tend to examine women's involvement in expeditions comparatively, so further examination of Aboriginal women's guiding is warranted.

Further afield, the work of anthropologist Johannes Fabian and historian Dane Kennedy on African women and expeditions offer insights on the importance of women to exploration. As Fabian has noted, the significance of their work was rarely acknowledged. His work has shown that the women travelled with their husbands, and often children too. ${ }^{6}$ They were central to food collection and preparation, diplomacy, influencing the mood of the party, relationships - intimate and otherwise - and were involved in dance and trade. Fabian discussed accounts recorded by Belgian and German explorers which recognised that women were especially adept at finding out information from others. Furthermore, Dane Kennedy's recent work includes discussion of intimate relationships between

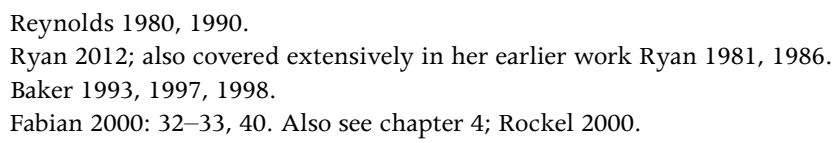


John Speke, Kahala and Meki, during Speke's 1862-1863 expedition to locate the source of the White Nile in Africa. Mentions of these relationships survived only in proofs and were not included in Speke's published expedition account. This suggests erasure and silences around women's intimate involvement, which can be difficult to trace in published expedition accounts; not only have women's experiences been hidden from history, they have been actively deleted. ${ }^{7}$

Historians have also unearthed the experiences of the guide Sacagewea who assisted the Lewis and Clark expedition in North America, and in South America the crucial role of Doña Marina has been discussed by Stephen Greenblatt. Doña Marina, fluent in Aztec, Mayan and Spanish languages was central to cross-cultural communication for Cortez in Mexico. Greenblatt notes that her gender was a significant factor in Marina becoming a go-between. She had been 'exchanged' by her own family as a girl, then enslaved and by necessity (and talent) she became skilled at negotiation, with an agenda of both revenge and survival. Cortez was reliant upon her for 'her linguistic ability, strategic information and for her grasp of MesoAmerican reality'. As Greenblatt explains it, Marina became 'at once his tongue and ears' and his mistress too. ${ }^{8}$ Alida Metcalf draws attention to Doña Marina, but also Damiana da Cunha who assisted on multiple expeditions and Margarida who initiated contact between Alvaro Rodriguez, the Aimore people and the Portuguese in seventeenth-century Brazil. Metcalf argues that Margarida's language skills, mobility and knowledge of both cultures made her an effective go-between. ${ }^{9}$ Such international scholarship offers useful comparative examples where women's guidance, especially in terms of their language and negotiating skills, can be seen. They suggest ways to explore the significance of Aboriginal women's participation in Australian exploration.

Rather than simply showing that 'women were there too', it is worthwhile considering how they vanished from view in histories. Part of the reason women have been excluded is related to the way some exploration histories have been written about, as solo heroic journeys of the expedition leader, as if there were no cooks, crews, intermediaries or anyone else there. As Fabian has remarked succinctly:

7 Kennedy 2013: chapter 7, especially: 195-198, 208, 223.

8 Greenblatt 1991: 141-145 and the rest of chapter 5.

9 Greenblatt 1991; Metcalf 2005: 1-2, 270-271. 
'Solitary explorers never travelled alone.' ${ }^{10}$ Felix Driver and Lowri Jones, and D. Graham Burnett have shown that expeditions were a collective act, with women as well as children involved. Indeed, on some occasions the men refused to travel without their female partners. ${ }^{11}$ In early Australian histories such as Ernest Favenc's History of Australian Exploration, masculinity and the figure of the explorer are intricately linked. Exploration is represented as white men's work alone, again obscuring women from view. In 1888, for example, Favenc described Australian exploration as 'the spectacle of one man pitted against the whole force of nature', and a few years later, Albert Calvert wrote of the explorers as a 'noble band of brave and devoted men' $^{12}$ Charles Long claimed to cover 'some of the exploits of those dauntless men, who took the chief part in opening up the continent' ${ }^{13}$ Even some more recent works can give the impression expeditions were an all-male enterprise, with remarks such as '[e]xploration parties always consisted of a team of men'. ${ }^{14}$ Some histories which quote extensively from explorer journals have noted the presence of women, if briefly, but the absence of women both Aboriginal and non-Aboriginal is persistent in many histories, nonetheless. It was less common for women to be involved in expeditions, so it follows that they feature less in exploration histories, but women did join and contribute significantly to some expeditions. While Aboriginal men's involvement in expeditions as guides and participants has been obscured in histories, Aboriginal women's guidance has been even more hidden.

Another reason women may have vanished from view is that Aboriginal women do not seem to have been hired 'officially' at the outset as guides. Women tended to join expeditions along the way, so they appear less often in expedition member lists, for example. Yet expedition work and participation was often more elastic than such lists suggest. Often the Europeans sought advice and assistance along the way and this tends to be when Aboriginal women's guidance comes into the picture. This is seen in the accounts of Thomas Mitchell,

10 Fabian 2000: 29.

11 Driver and Jones 2009: 13; Burnett 2000: 23; 2002: 29-30.

12 Favenc 1888: vi; Calvert 1895: preface.

13 Long 1903: 219.

14 Cathcart 2001: 234. 
Charles Sturt and Robert Hoddle in eastern Australia, where women provide information on country ahead and the location of water to either Aboriginal guides or the explorers themselves. ${ }^{15}$

Historians also bring presumptions about Aboriginal women, their authority and their agency to the sources, which can block the women from view. As Kay Schaeffer has noted, using Mary Louise Pratt's idea of the contact zone (a space in which colonised and coloniser interact and where power dynamics are not always clear cut): 'Women both white and Aboriginal have been consistently left out of considerations about the nature of $\ldots$ contact zone experience. ${ }^{16}$

When Aboriginal women are included in exploration histories they are not widely represented as adventurous, skilled communicators or even as expert travellers.

Selective and repeated use by historians of accounts where Aboriginal women are portrayed as victims of 'savage' violence, without careful consideration of other coexisting representations, continues to influence analyses, as Ann McGrath and Shino Konishi have shown. ${ }^{17}$ Violence happened, and should be recognised, but it was not the only experience women had. Aboriginal women as well as Aboriginal men may have sought to develop what Tiffany Shellam has described as 'travelling knowledge': information gained through expeditions about distant people and country as well as colonists, which could be used to increase their status within their own community and beyond. ${ }^{18}$ Heather Roller notes that Amerindian crew members who joined

15 Charles Sturt noted that women approached the expeditioners camp on the Darling and enjoyed some tea with them (Sturt 1965 [1849]: 133). Robert Hoddle, travelling towards the Shoalhaven, New South Wales, in 1827, recorded that 'On the evening of the $19^{\text {th }}$ Friday, I met with two native black women, with two children who shewed me the water holes', cited in Colville 2004: 110. During Mitchell's 1845 expedition, two women told Mitchell's guide, Piper, where permanent water could be found around Nyngan, NSW, and beyond (Mitchell 1848, 17 January 1845: 36). An older woman advised Edmund Kennedy, NSW Assistant Surveyor General, of the course of the Balonne River (in Mitchell 1848: 357). The singing and dancing of women is also remarked upon by Mitchell in this entry.

16 Schaeffer 2001; Pratt 1992: 7. Assumptions also exist in relation to white women and expeditions, though since the 1990s especially several studies have addressed this such as Birkett 1989; Mills 1991; Blunt 1994 and others.

17 Konishi 2008; McGrath 1990.

18 Shellam 2009: 138-153. 
collecting expeditions in the Amazonian Sertão may have sought opportunities to travel and to visit relatives; Aboriginal women may have pursued chances to do the same. ${ }^{19}$

Traces of Aboriginal women's roles in expeditions can be found in some explorers' published journals, if not always in exploration histories. The journals are problematic sources for a study of Aboriginal women's participation, being representations by white men who may have downplayed women's actions and the accounts were not written from the women's perspectives. Often Aboriginal women are unnamed, making the tracing of their histories harder. Yet, sometimes the journals contain reported speech and accounts of their actions, which can be read 'against the grain' to provide at least some sense of creative Indigenous responses to expedition encounters. ${ }^{20}$ Bronwen Douglas has argued 'countersigns' - indications of local agency and strategy within foreign/coloniser representations of local people - can be teased out in such accounts. As she explains it, 'the presence and agency of Indigenous people infiltrated the writings and pictures produced by sailors, naturalists and artists ... and left ambiguous countersigns in the very language, tone and content of their representations'. ${ }^{21}$ Such traces can point to moments where women's agency was shown, even if it is perhaps a fraction of what they did. Much activity by guides also remained unremarked in journals until conflict or problems occurred, as Burnett has shown. ${ }^{22}$

Mentions of Aboriginal women's guidance on Australian expeditions can be found in the published accounts of James Grant, Thomas Mitchell, Robert Hoddle, Edward Eyre, George Augustus Robinson, George Fletcher Moore and, later, William Hann and David Carnegie. The latter took women hostage to show him where water was in northern Australia - a reminder that not all participation in expeditions was voluntary. ${ }^{23}$ These were a few of the explorers who wrote about women and expeditions. Aboriginal women's leadership

19 Roller 2010: 467.

20 Reynolds 2006: 4.

21 Douglas 2014: 21-22; Douglas 2009: chapter 6.

22 Burnett 2002: 7, 29. See also Kennedy 2013: 163-164 and Wisnicki 2010 regarding the impact of non-Western dynamics and events on published and unpublished expedition accounts. 23 Carnegie 1898. Leichhardt's 1844-1845 journal mentions that the male Aboriginal guide Gnarrangan 'intended to take his wife with him' on the expedition, Leichhardt 1847, 10 December 1845: 523. 
of informal expeditions is occasionally mentioned in non-Aboriginal women's accounts too. Amateur anthropologist Ethel Hassell wrote about Aboriginal women taking her on bush explorations in southwest Western Australia in the 1870s, for example. Botanical painter Ellis Rowan wrote of a trip up Mt Macmillan in Queensland where Aboriginal women carried provisions and laughed at the bumbling movements of the white people. ${ }^{24}$

\section{Trugannaner, Pagerly, Dray, Timemedene and George Augustus Robinson's Port Davey expedition, Tasmania, 1830}

Aboriginal women as well as men provided guidance for missionary George Augustus Robinson in the initial expedition to 'conciliate' Aboriginal Tasmanians in 1830 to Port Davey and the west. ${ }^{25}$ Before the expedition commenced, Robinson proposed to Governor Arthur a program of conciliation, to bring in Aboriginal people for their own safety, to civilise and covert them to Christianity. Robinson stated that he had discussed the trip with the people living on Bruny Island, where he had been overseer since March 1829. Some of these people were from Port Davey originally, and had come to stay on the island for a while. Reynolds, however, argues that the group regarded the expedition as a regular seasonal journey to the West Coast and that they happened to agree to take Robinson with them. ${ }^{26}$ Other circumstances probably influenced their decision to travel with him also.

The expedition took place after much illness on Bruny Island and the ongoing violence of the Black War in Tasmania. Aboriginal people were being shot at in areas pastoralists were occupying, and in the north-west islands some sealers had kidnapped women. As Lynette Russell has shown, Aboriginal people's relationships with sealers were far more complex and varied than the simple uniform story of

\footnotetext{
24 Hassell 1975, also cited in Reynolds 1990; Rowan 1898: 119-124.

25 Aboriginal women worked as guides for John Batman in Tasmania (1830) also, to assist with 'bringing in the tribes'. Batman 1830: n.p.

26 Reynolds 2012: 71-72. See also Burnett regarding Amerindians in British Guiana's possible consideration of the traveller Schomburgk as 'their temporary passenger'. Burnett 2002: 29.
} 
kidnapping that Robinson's account suggests. ${ }^{27}$ Either way, retaliatory violence was rife and pressures upon Aboriginal Tasmanians were increasing, which may have influenced their decision to join Robinson.

Robinson, his son Charles, Tom, Robert, Dray, Pagerly and Trugananner, Woorraddy (Trugananner's partner) and his sons set off from Recherche Bay overland to Port Davey on 3 February 1830, amidst blustery southerly winds. ${ }^{28}$ Robinson referred to their route as the 'track of the natives', and claimed that 'no person had ever attempted it'. ${ }^{29}$ They were a party of 14 , including six convicts as well as support vessel staff who dropped food and supplies to key points on the coast. They spent four months away in the west of Tasmania, an area that is still remote and rugged today.

The focus of most work on this expedition and Robinson's account (first published in 1966) has been on Trugananner, rather than the other women involved. Much work debates her participation in moral terms: Did she betray her people? Was she emotionally entangled with Robinson? Or was she a survivor? Lyndall Ryan has examined such representations and debates closely, drawing out culturally contextualised and historicised readings of Trugananner's involvement. Ian Anderson has reflected upon the way Trugannini has been represented symbolically, in ways which have denied Tasmanian Aboriginal identities, survival and histories. ${ }^{30}$ Henry Reynolds has also critiqued moralistic and sexually preoccupied accounts of Trugananner's participation and argued the case for Trugananner acting politically in assisting Robinson. He argued that women were crucial negotiators and he recognised the contribution of Dray and others. ${ }^{31}$ His interpretation centres mostly on Aboriginal people's political action and treaty making, but other reasons for participation are worth considering more closely too.

28 Robinson 2008, 3 February 1830: 143. See also pages 142-144, Plomley's summary on pages 154-155.

29 Robinson 2008, 3 February 1830: 143. See also pages 142-144, Plomley's summary on pages 154-155.

30 Anderson 1995, 2008.

31 Ryan 2012; Reynolds 1995. 
Trugannaner was aged around 17 at the time of the expedition. In 1876 she stated that her 'fiancé' Paraweena had been killed by sawyers in 1828, her sister Moorina was 'taken away' by sealers, her other sister shot, her mother stabbed to death by men who came onshore, while her father was shot by a soldier. ${ }^{32}$ After such loss, amidst illness and frequent deaths on Bruny Island, it may have seemed to her that she had little left to lose by leaving. She had relatives in the area they were heading to, which was likely to have influenced her decision to go. ${ }^{33}$

Dray was a widow, around 30 years old, and her child had become ill and died on Bruny Island not long before the expedition started. She had chosen to stay with sealers and had avoided Robinson at times. ${ }^{34}$ She was from Port Davey originally and Robinson took her as a guide because this was her country and language group so he anticipated she would prove helpful with translations and introductions. Robinson recorded her motivation: 'One of the women named DRAY said she should now see her brother. ${ }^{35}$ Visiting family and country seem likely motivations for joining forces with Robinson.

Another guide mentioned was Pagerly who was from the southeast region of Tasmania and was living on Bruny Island. She was approximately 18 years old at the time the expeditions began. Less is known about her background. Other women such as Sall were involved in subsequent Robinson expeditions as guides.

Before the expedition party did much negotiating or interacting with local Aboriginal people, they encountered difficult travel conditions in thickly forested areas with swift-running rivers. The women, as well as the men, worked to clear and recut the path through the forest, and advised of the best way through, literally making the way forward. ${ }^{36}$ Robinson soon found that their European provisions were almost exhausted. It was the Aboriginal women and men who kept Robinson and the convicts from starvation. Robinson survived on mussels, roots, berries and fish that they procured ${ }^{37}$ He noted that

32 Graves 1876: 3; Robinson 2008: 49.

33 Ryan 2012; Miller and Cameron 2011.

34 John Freake (a convict), 27 November 1829, in Robinson 2008: 122, n. 49; Robinson 2008,

11 September 1830: 81.

35 Robinson 2008, 30 January 1830: 115.

36 Robinson 2008, 11 March 1830: 156.

37 Robinson 2008, 19 February 1830: 151. 
the women fished and collected crayfish and that they brought him wild duck eggs too. They had specific skills in hunting and gathering, which enabled his survival. Trugananner and Pagerly also collected and carried provisions and heavy gear according to Robinson.

Importantly, the Aboriginal women were part of groups who tracked local people and initiated discussions with them, brokering between Robinson and the local people and mediating on behalf of Robinson. He described how this was done:

[A]fter observing for some time the movements of the natives they stripped themselves of their European clothing and went in quest of them. At 7pm Trugananner, Pagerly and Woorrady returned and informed me that they had been with the Port Davey natives and that the other woman DRAY had stopped behind, having met with her brother. They further stated that they had made the Port Davey natives understand the nature of my mission to them, and said the Port Davey natives was anxious I should come to them in the morning. ${ }^{38}$

What was actually said remains unknown, though the women clearly used this as an opportunity to reconnect with family and share information. It was the Aboriginal women and men, not Robinson, who brokered contact.

Dray returned the next day with two young Port Davey women. Robinson 'performed' at their initial meeting; he tried to charm them by playing the flute, and encouraged them to try novel food such as biscuits. Yet they were assessing him as much as he was them. He sent them in quest of others - but they returned saying they could not find them. Considering their skills in tracking, the women may have chosen not to locate them, or the others may have decided to avoid him.

The significance of women in keeping watch and alerting others to danger is also apparent in Robinson's account. Dray and Wooraddy tracked a group after spotting their abandoned fire and meal. They found around 15 women and children, whom Dray asked to come out of hiding. Again, Robinson sat by the fire, offered food, beads and trinkets, and noted 'the women began to hoot a signal for the men to 
come home' ${ }^{39}$ Here, the women assessed the situation and advised the men that it was safe for them to return to camp. Still, they refused to camp with Robinson and they departed overnight. ${ }^{40}$

Five days later, the explorers followed local people to a river Robinson described as a 'rendezvous for the natives'. The camp that Robinson's group joined later was located near plenty of ripe kangaroo apples, which suggests this was likely to have been a key time for gathering to feast on them. The expedition's camps possibly had other meanings for the women and men, for example, the timing coinciding with their own social and cultural calendar of movements. A celebration on the reuniting of relations followed at the 'Friendly River' camp:

The evening was spent with great conviviality, singing and dancing until a late hour, make the woods to echo with their song. The song they call Lun.Ner.Ry and the dance True.De.Cum. My blacks danced and sung in their turn. ${ }^{41}$

Gatherings like these over subsequent nights suggest the social and family connections were key considerations for Aboriginal people in the party and those they were visiting or returning home to. Aside from the dancing and singing, other clues indicate they were trying to bring Robinson into their world: 'At the request of the natives had my face painted black. The natives continually painting themselves.' ${ }^{42}$ The symbolism is hard to miss.

Shortly after the feasting evening, the women's finely honed observation skills were shown. One of the Port Davey women alerted the others to the pistols in Robinson's knapsack and was appointed to guard him, taking on an important role of protection:

The circumstances of these pistols induced them to place a watch before my hut and this duty was assigned to one of the young females, I suppose from being less likely to excite suspicion. This woman never left her post, whatever the weather might be. Frequently the rain fell in torrents, yet she remained firm to her duty. ${ }^{43}$

41 Robinson 2008, 25 March 1830: 168. March is when kangaroo apples tend to ripen, though this varies depending on seasonal conditions.

42 Robinson 2008, 28 March 1830: 171.

43 Robinson 2008, 26 March 1830: 168-169. 
So much for Robinson's claims of his peaceful, unarmed negotiation. The women often acted as lookouts and watched him as he slept; their skills clearly valued by their own people and, when used for his purposes, by Robinson too.

Dray played a key role in providing explanations of the Aboriginal people's behaviour to Robinson - or at least explanations that she thought he could accept. She explained to him why the people they met were afraid, not only of the white men but also some of the male Aboriginal guides who had been in roving parties, which had captured Aboriginal people. He wrote, revealingly, '[they] called all my blacks Num viz white people', suggesting the suspicion that their prior behaviour and 'new' ways caused. ${ }^{44}$

Dray educated Robinson about negotiating with her people, insisting that he waited until she had spoken to them first, taking on a leading role. As Henry Reynolds has argued, these negotiations were Aboriginal ones, pursued by them rather than Robinson and for their own purposes it would seem. ${ }^{45}$

Dray and her Port Davey group left the camp at the Little Rocky River area before dawn without telling Robinson, which he regarded as a betrayal. ${ }^{46}$ He does not appear to have considered that they may have had their own reasons for moving on, even though numerous people came and went and would not stay constantly with him. Such episodes where guides vanished or unexpectedly departed an expedition can reveal that intermediaries had their own agendas and terms of interaction, as Kennedy has shown. ${ }^{47}$

The women were also essential to the expedition because of their swimming abilities. The Aboriginal men built vessels from bark, which Robinson described as 'catamarans' in order to cross the numerous rivers in the region, but it was often the women who swam ahead and steered them across. Aboriginal women were the expert swimmers and divers in their communities, responsible for collecting abalone, mussels and crayfish, these skills being adapted to expedition purposes. This was especially important as Robinson could not swim

\footnotetext{
44 Robinson 2008, 30 March 1830: 172.

45 Reynolds 1995: 139.

46 Robinson 2008, 7 April 1830: 176-177.

47 Kennedy 2013: 187.
} 
and would not have been able to get far without them. ${ }^{48}$ Trugananner, Dray and two Port Davey women who joined them, Timmedenne and Wyyerer, made sure all the luggage was safely transported over and then the children were taken across. They made several trips across the river, in chilly water. ${ }^{49}$

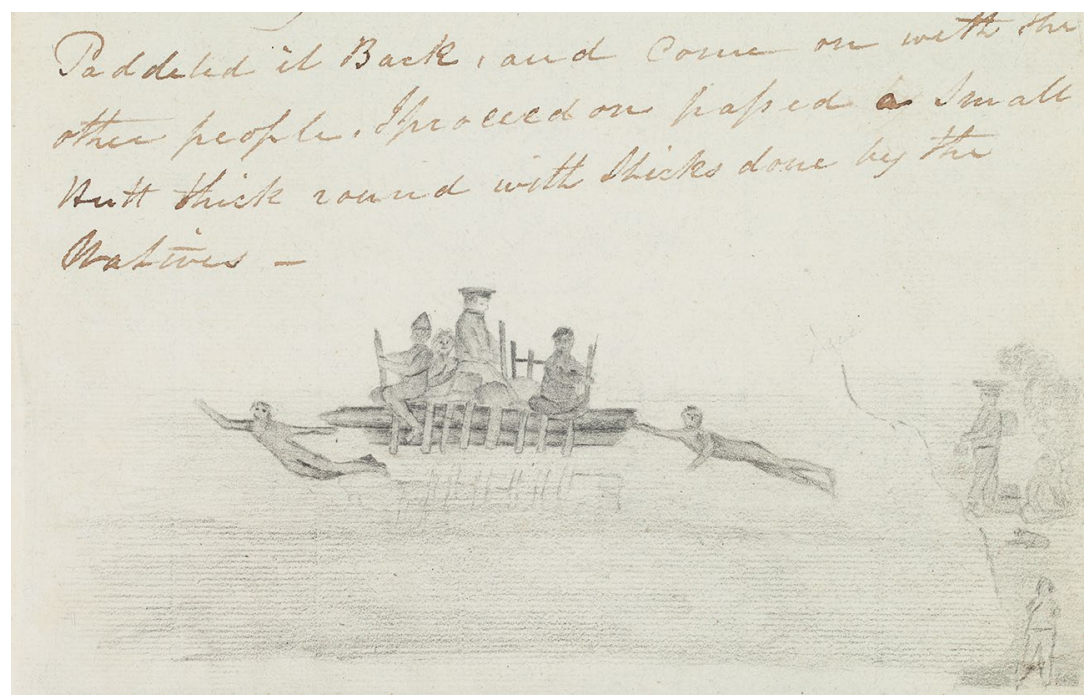

Figure 5.1: George Augustus Robinson, Aboriginal women and men taking Robinson across the river, 10 June 1830.

Source: George Augustus Robinson, Journal Van Diemen's Land, 10 June 1830, Vol 6, A7027, Cy reel 266, Mitchell Library.

The women's swimming skills were also useful in attempted negotiations when they reached areas where sealing communities lived, such as Green Point. Some of the women fled into the sea in a desperate attempt to escape the white men (either having being shot at, raped or kidnapped before, or highly aware of this as a possibility). Dray and Trugananner swam out to them and attempted to talk with them. ${ }^{50}$

The Aboriginal women were important also in gaining the confidence of some of the sealing community women who told them of being captured. They provided testimonies about massacres and cruelties 
that they had experienced at the hands of sealers and pastoralists. Robinson used this information to build his case for further expeditions and intervention in the communities, devising a case for removing women from the sealers. It is not clear whether he made this purpose explicit to Dray, Trugananner and Pagerly. The responses of some of the sealing women on Robbins Island to the arrival of the women suggests again that reuniting with relatives and people such as 'Jack' and 'Maria' was an important part of the expedition for those visited: 'the sealer women appeared remarkable fond of my aboriginal females, caressing them and kissing them incessantly. As they were eastern women my aborigines could converse with them. ${ }^{51}$

By the time the expedition made it to George Town on the mouth of the Tamar River in northern Tasmania, after travelling inland to the Hampshire and Surrey Hills, non-Aboriginal people were being incited to take up arms and join in the Black Line. From this point, the expeditions increasingly seemed to be about the capture and removal of people from country for Robinson, rather than negotiation, which was his original stated intention. As Lyndall Ryan, Henry Reynolds and James Boyce have all noted, Robinson's journals show him becoming more forceful (and arrogant, presuming he could out-track Aboriginal people, for example) after this. He ultimately allowed force to be used to have people sent to Flinders Island - a major change in approach from this initial Port Davey expedition. ${ }^{52}$

\section{Kitty, Turandurey and Ballendella and Thomas Mitchell's expedition in New South Wales and Victoria, 1836}

On the much drier mainland, in 1836, Aboriginal women and men acted as guides in the third and final journey of Thomas Mitchell's expeditions as Surveyor General of New South Wales, in eastern Australia. The expedition was instructed by the governor to finish the survey of lower Darling River where it joined the Murray River, though

51 Robinson 2008, 21 and 24 June 1830: 212-217.

52 Ryan 1981; Reynolds 1995; Boyce 2008. 
it also ventured into the 'Australia Felix' (Victoria). The underlying aim, however, was to seek and find land suitable for grazing cattle and white occupation.

Mitchell's published account of 1839 clearly described Turandurey as a guide. ${ }^{53}$ Nineteenth-century historians William Pridden and William Howitt mentioned Turandurey and Kitty in their histories, and more recently Dane Kennedy has mentioned Turandurey briefly. ${ }^{54}$ Donald Baker's work on Mitchell and his relationship with Aboriginal guides brought Turandurey and Kitty to the fore, noting their language skills, knowledge of country and gender protocols around meetings. However, Baker occasionally treats Mitchell's account as literal truth, rather than representation, overlooking alternative readings of behaviour and actions of Aboriginal participants. ${ }^{55}$

Mitchell's party of 23, complete with a cook, bird collector, medical assistant, butcher and others met at the preparation camp near Bathurst in $1836 .{ }^{56}$ The waterholes were low and the country parched by drought when Piper, an Aboriginal man, approached Mitchell to assist the expedition, on the condition he was fed, clothed and had a horse ${ }^{57}$ While he was referred to by Mitchell as an interpreter and brokered others guiding, he was effectively the main guide for the expedition. Mitchell's account shows that several men, such as Barney, and women also provided guidance along the way. One of these women was Kitty, who joined Piper near Lake Cargelligo/Cudjàllagong in Wiradjuri country after he temporarily left the expedition party to 'marry' her. Piper had spoken of 'obtaining a gin' in the area as a motivation for heading there. ${ }^{58}$ Mitchell introduced Kitty: 'a good strong woman marched behind him into our camp, loaded with a new opossum-skin cloak, and various presents that had been given to Piper with her. ${ }^{59}$

\footnotetext{
53 Mitchell 1839: 40. Athenaum, September 1838, also published excerpts from the text which mentioned Turandurey as a guide.

54 Howitt 1865: 294, 298; Pridden 1843: 180-184.

55 Baker 1997.

56 The camp was in the 'Valley of Canobolas' in Mitchell's terminology.

57 The overseer Alexander Burnett knew Piper and suggested to Mitchell that he come with them.

58 Mitchell 1839, 15 April 1836: 37.

59 Mitchell 1839, 15 April 1836: 37.
} 
Mitchell presumed Kitty was from a 'strange' tribe, little known to Piper while Granville Stapylton, the second-in-command (whose journal was first published in 1986), represented the marriage as an act of abduction: 'In one short space Piper talks to them in a conciliatory mood and in another robs them of a daughter. ${ }^{60}$ That Piper conversed with them at length and that Kitty had been given a cloak and gifts suggests that their union was organised and communicated between Kitty and Piper's people well ahead of Piper's arrival. The timing of this marriage may even have been central to Piper joining the journey at this point, as well as the material benefits.

Kitty proved a valuable guide, both with Piper and independent of him, informing the party of where they would find water, such as at Combèdyega. ${ }^{61}$ She appeared regularly throughout Mitchell's narrative as part of negotiations with groups they encountered. She was with the party when it was negotiated that Turandurey, a widow aged about 30, join the expedition with her young daughter. This occurred after they reputedly 'surprised' an Aboriginal group. Two children remained by the cooking fire after the expedition group had retreated, watching. The rest of the group re-emerged and exchanges commenced soon after:

An old man came up to the fire afterwards, with other children. He told us the name of the water-holes between that place and the Murrumbidgee, but he could not be prevailed on to be our guide. Subsequently, however, a gin who was a widow, with the little girl above-mentioned, whose age might be about four years, was persuaded by him to accompany us. ${ }^{62}$

Mitchell did not discuss Turandurey's possible reasons for joining the expedition with her daughter Ballandella, but he noted the considerable assistance she provided to the party. Turandurey gave directions on which way to head, where to find water and where to camp - an expert on her country, the Lachlan Plains. She shared guiding responsibilities with Piper and Kitty. ${ }^{63}$

\footnotetext{
60 Stapylton 1986, 14 May 1836: 61.

61 Mitchell 1839, 2 May 1836: 60.

62 Mitchell 1839, 2 May 1836: 60.

63 Mitchell 1839, 6 May, 7 May 1836: 60-61.
} 


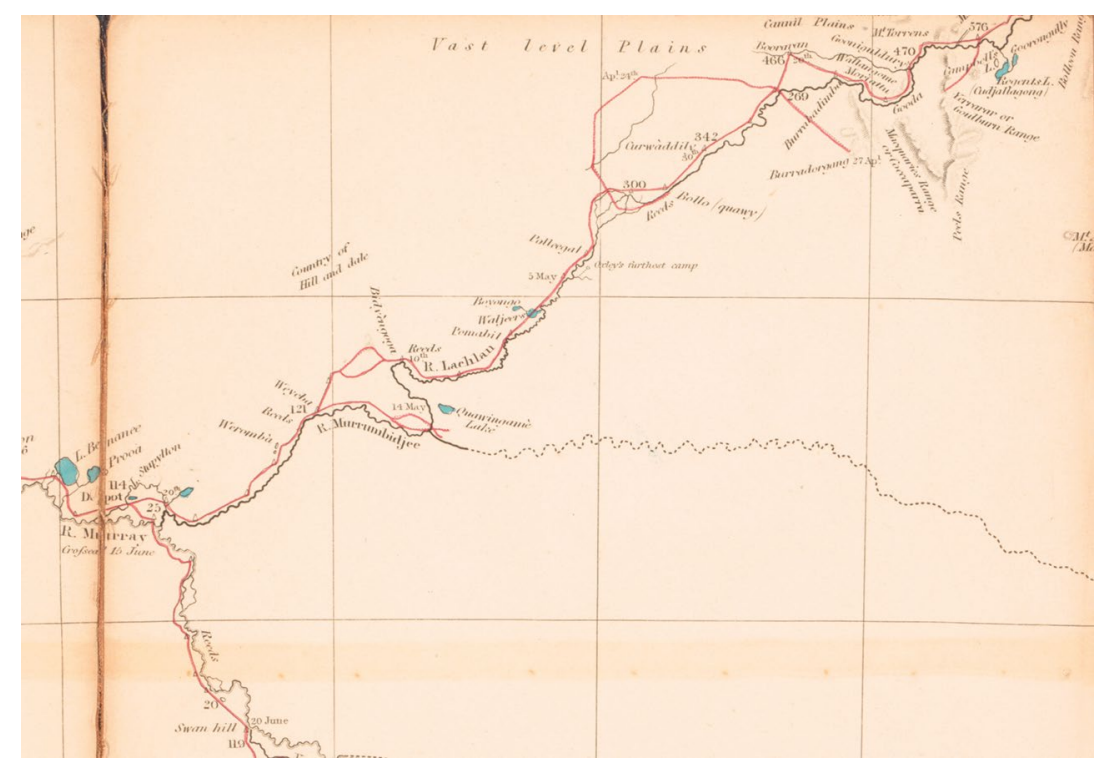

Figure 5.2: Detail from map by Thomas Mitchell, 'The south eastern portion of Australia showing the routes of the three expeditions and the surveyed territory', 1838, which noted the camp and the name of the waterhole, Pomabil, that Turandurey guided Mitchell's party to.

Source: Thomas Mitchell, Three Expeditions in the interior of Australia, 1838, MAP NK 1476, National Library of Australia.

At first glance, some of the women's guiding appears to be a straightforward response to Mitchell's requests - for example, he asked them to locate the furthest point John Oxley's 1817 exploration party reached on the Lachlan River. The women showed him this site, but they also pointed out that one of Oxley's men nearly drowned there and that they rescued him. They mentioned three white men on horseback and their canoes (boats) on the Murrumbidgee. Such specific, located memories reveal just how keenly observed 'strangers' in country were, offering a view back from people who lived on this country. Perhaps this was intended to remind Mitchell that he was being watched too. ${ }^{64}$ The women's accounts drew attention to the assistance they provided to the expeditions and could also be seen as an assertion of their knowledge and ownership of place. 


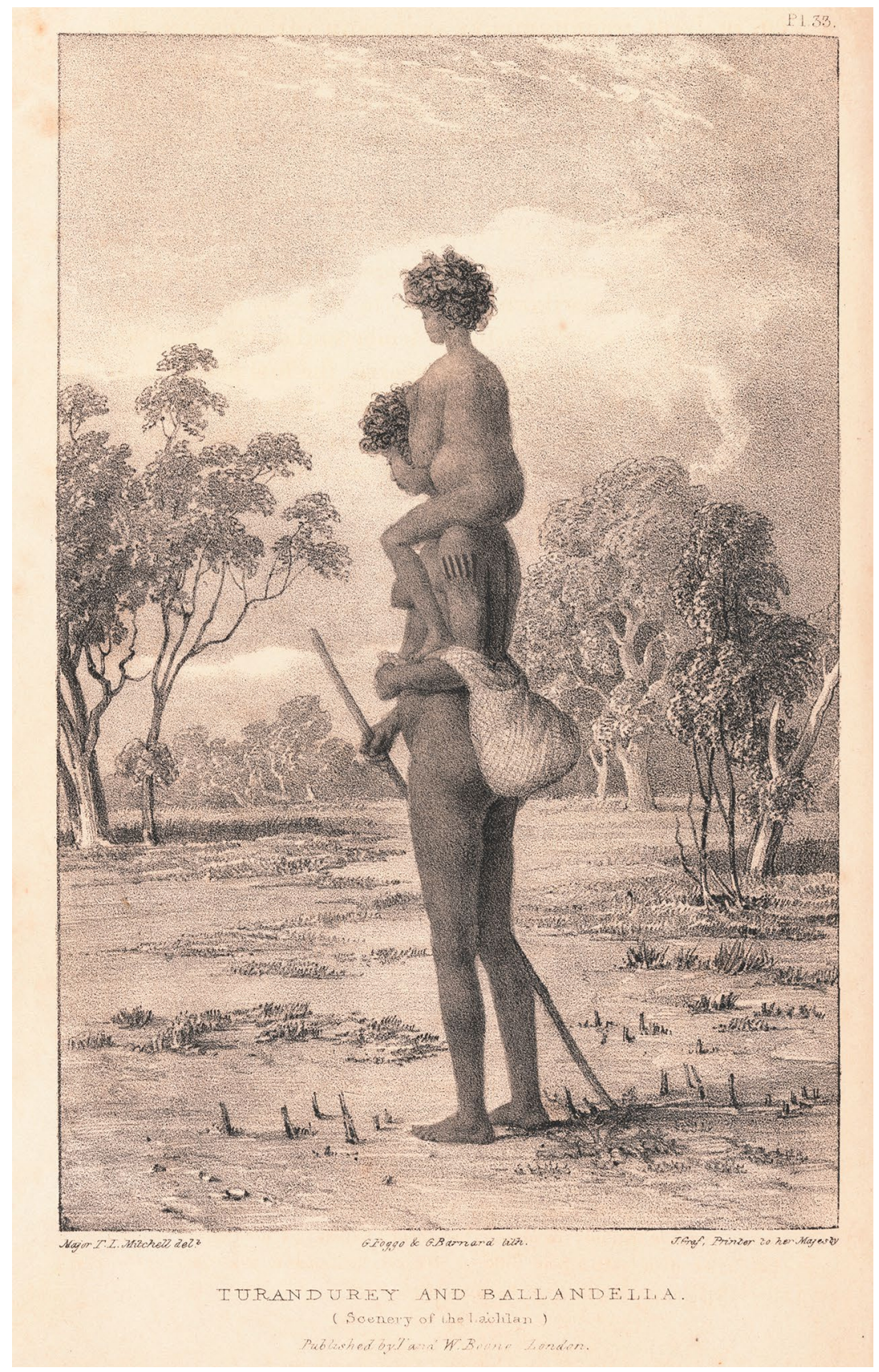

Figure 5.3: Portraits of Turandurey (the female guide), and her child Ballandella, with the scenery on the Lachlan (10 May 1836). Source: Thomas Mitchell, Three Expeditions in the interior of Australia, 1839: 68-69 (Plate 34), National Library of Australia. 
Later, in a move reminiscent of Dray's actions in Tasmania, Turandurey pursued and talked with a family. While Mitchell wanted Piper to ask the elderly man of the Murrumbidgee group questions, he remained silent. Neither Piper nor the man would look at each other, or speak, as protocol demanded. Turandurey intervened:

The female, however, became the intermediate channel of communication, for both spoke alternately in a low tone to her ... by slow degrees, they got into conversation. We were then informed that water was to be found a mile or two on, and the old man agreed to guide overseer Burnett and Piper to the place. ${ }^{65}$

She negotiated Mitchell being able to travel through this country. Further along the Murrumbidgee, Turandurey proved a crucial intermediary for the party and, later still, she initiated discussions with a group on the riverbank, before Mitchell caught up. He saw this as a gendered skill she brought to the expedition, though it may have been shaped by her status/relationship to the speaker in other ways too:

it appeared that while some diffidence or ceremony always prevents the male natives, when strangers to each other, from speaking at first sight, no such restraint is imposed on the gins; who, with the privilege of their sex, are ever ready to speak ... ${ }^{66}$

The guides appeared to have enjoyed appearing worldlier than the group they spoke with, the women laughing at the Aboriginal men's request to have the 'wild' sheep and horses sent away. ${ }^{67}$

In this case, Turandurey played a significant role in opening up communication for the party and ensuring her own safe passage through the area. Turandurey and Kitty were sent ahead by Mitchell at various points to negotiate. In addition to this ability to be a conversation conduit, women were perhaps seen as less threatening to 'strangers'. 
Turandurey also appears to have had a talent for entertaining the party, impersonating Mitchell's 'explorer' activities in the field: 'I was informed that the widow could also amuse the men occasionally - by enacting their leader, taking angles, drawing from nature, \&c. ${ }^{68}$

While only a fleeting mention, it alludes to a different perspective on exploration and provides a sense of how odd the practices of Mitchell and others may have looked to her. On other expeditions some similar revealing moments were recorded. For example, in George Fletcher Moore's account of an expedition north of the Swan River in Western Australia, Toodyep questioned why he walked so much in the bush and she mimicked Moore's words of wisdom, to the amusement of the other Aboriginal people present. ${ }^{69}$ As Simon Ryan has argued, 'mimicry is the best possible method of indicating that the explorers are subject to Aboriginal surveillance'.$^{70}$

Turandurey and Kitty answered Mitchell's queries and provided cultural explanations when grave sites were encountered. When Mitchell noted a shelter and asked about it, the women imparted information connected to child rearing that the Aboriginal men either would not comment on. They reputedly told Mitchell 'it was usual to prepare such a bower for the reception of a new-born child' ${ }^{71}$

Their commitment to the expedition was not always unwavering. Turandurey and Kitty wanted to leave, which Mitchell stated was due to Turandurey being beyond her own area and worried that he would take her daughter from her. ${ }^{72}$ Her daughter, Ballandella, had a broken leg from a cart accident earlier in May, and they had waited for it to heal after the expedition's medical attendant, John Drysdale, treated her. The ever-suspicious Stapylton saw signs of 'collusion' between the 'wild' tribes and Turandurey. ${ }^{73}$ She may have merely sought information to ensure her way back was safe. They left,

\footnotetext{
68 Mitchell 1839, 27 September 1836: 277.

69 Moore 1836a: 692, 693; Moore 1884: 387. Moore noted they were surprised at the collections of shrubs by the botanist Ludwig Preiss, and 'are very curious to know what he does with them', questioning the premise of botanical collecting. Imbat asked a starving George Grey in north Western Australia why he did not stay where there was food and he could be fat and handsome. Grey in Howitt 1865: 387.

70 Ryan 1996: 187-190.

71 Mitchell 1839, 7 September 1836: 251-252.

72 Mitchell 1839, 3 July 1836: 162-163.

73 Stapylton 1986, 23 May 1836: 74.
} 
swimming across the Millewa/Murray River, Turandurey pushing Ballandella ahead of her on a bark sheet, but they ultimately returned. The Aboriginal people on the opposite bank, angry on seeing her fire, asked who went there. Turandurey and Ballandella retreated through the frosty night. ${ }^{74}$ This episode suggests the precariousness of the guide's position. Alliances with white explorers could also open up the potential for conflict between groups, making it a risky role to take on.

Turandurey and Ballendella remained at the depot camp, beyond the junction of the Murray and Lachlan, with Stapylton and others. However, Kitty continued with Mitchell after Piper argued the case for her joining them. ${ }^{75}$ They travelled on to the junction of the Murray where Mitchell came face-to-face with the daughters of the woman his party had killed on his Darling River expedition a year earlier. They had travelled down to confront him, according to Piper. Though reputedly filled with regret about the death, Mitchell managed to observe that the younger of the two daughters was attractive. His interest noted, the 'chief' offered Mitchell intimacy with her in exchange for a tomahawk. Perhaps Mitchell had misunderstood and 'the chief' was explaining that Mitchell had obligations to provide for the daughter, being connected with the killing of her mother. ${ }^{76}$

During this tense time, Kitty was represented as an important scout for gossip and intelligence, faithfully reporting back to Mitchell. ${ }^{77}$ He does not seem to have considered that she may have been tipping them off. With Piper, Kitty watched and explained to Mitchell the tactics of a group that shadowed them, and then pulled back. He noted that they were:

strong men, neither women nor boys being among them; and although we had little to fear from such an attack, having arms in our hands, the scheme was very audacious. ${ }^{78}$

\footnotetext{
74 Mitchell 1839, 6 July 1836: 162, 165. According to Stapylton, Piper tracked them: 124-125.

75 Stapylton 1986, 2 July 1836: 125.

76 Mitchell 1839, 24 May 1836: 93.

77 Mitchell 1839, 24 May and 1 June 1836: 94, 112.

78 Mitchell 1839, 1 June 1836: 111-112 (my emphasis).
} 
Mitchell and other explorers read a lack of women and children's presence among Aboriginal groups as a sign of hostility toward the expedition. ${ }^{79}$ Even when women were not actively involved in guiding expeditions, some explorers considered their presence or absence attentively.

Kitty proved valuable to the party again when violence erupted. It was likely to have been a response to previous violent encounters on the Darling River with Mitchell's party in 1835. Local Aboriginal people told Daniel Brock, gunsmith and bird collector on Charles Sturt's inland expedition in 1844, that convict members of Mitchell's party had raped and killed a woman and then killed her child there.$^{80}$ As Mitchell represented the situation, the Darling people had followed them and approached them with spears and one of his men fired on them. Seven Aboriginal people died as the rest of the party opened fire. Mitchell named the place 'Mt Dispersion'. During this chaos, Kitty became an impromptu guard, watching over the horses and cattle, gear and provisions that the men had abandoned. Mitchell celebrated her quick thinking. ${ }^{81}$

Women were knowledgeable about places and could read country and cues from the environment, having been schooled in this from childhood. Mitchell recognised that the women guides' directions and assistance were important:

[the] native party usually explored the woods with our dogs, for several miles in front of the column. The females kept nearer the party, and often gave us notice of obstacles, in time to enable me to avoid them. My question on such occasions was, Dāgo nyōllong yannāgary? (Which way shall we go?) to which one would reply, pointing in the proper direction, Yalyāi nyōllong-yannār! (Go that way.) ${ }^{82}$

79 Mitchell 1839, 24 May 1836: 94; Sturt 1849: 133-134.

80 Brock 1975, 16 October 1844: 50-51. In Brock's account, Topar, an Aboriginal expedition guide, showed Brock where he witnessed the killing, the marks of the shots on the tree and the graves. Sturt mentioned an 'unhappy occurrence that took place between them and Sir Thomas Mitchell during a former expedition', Sturt 1965 [1849]: 99.

81 Mitchell 1839, 27 and 28 May 1836: 103.

82 Mitchell 1839, 19 June 1836: 135. 
It is likely they were carefully leading him in particular ways, managing the presence of the party so that key powerful places were avoided. As in Tasmania, the women knew how to steer craft across rivers and assisted Mitchell with transporting his specimens and papers safely across to the riverbank. ${ }^{83}$

It was through Piper, Kitty and Turandurey's interactions with local people that Mitchell was able to find names for his maps, water, and route advice, often from families. This is a reminder that it was a domestic landscape that the explorers were moving through, a place of families; not just men, but women and children too. In a valley near the Wando River in western Victoria this was clearly shown:

I perceived at length two figures at a distance $\ldots$ as the female saw us, she began to run. I presently overtook her, and with the few words I knew, prevailed on her to stop, until the two gins of our party could come up; for I had long been at a loss for the names of localities. This woman was not so much alarmed as might have been expected; and I was glad to find that she and the gins perfectly understood each other. The difference in the costume on the banks of the Wándo, immediately attracted the notice of the females from the Lachlan. The bag usually carried by gins, was neatly wove in basketwork, and composed of a wiry kind of rush. She of Wándo carried this bag fastened to her back, having under it two circular mats of the same material, and beneath all, a kangaroo cloak ... The boy was supported between the mats and cloak. ${ }^{84}$

The guide's curiosity about other women's appearance and practices are evident here, showing some of the different experiences that participation in an expedition might bring for guides, possibly increasing knowledge of people distant from their usual travel routes.

83 Mitchell 1839, 3 November 1836: 336.

84 Mitchell 1839, 10 August 1836: 212. 
5. GUIDED BY HER

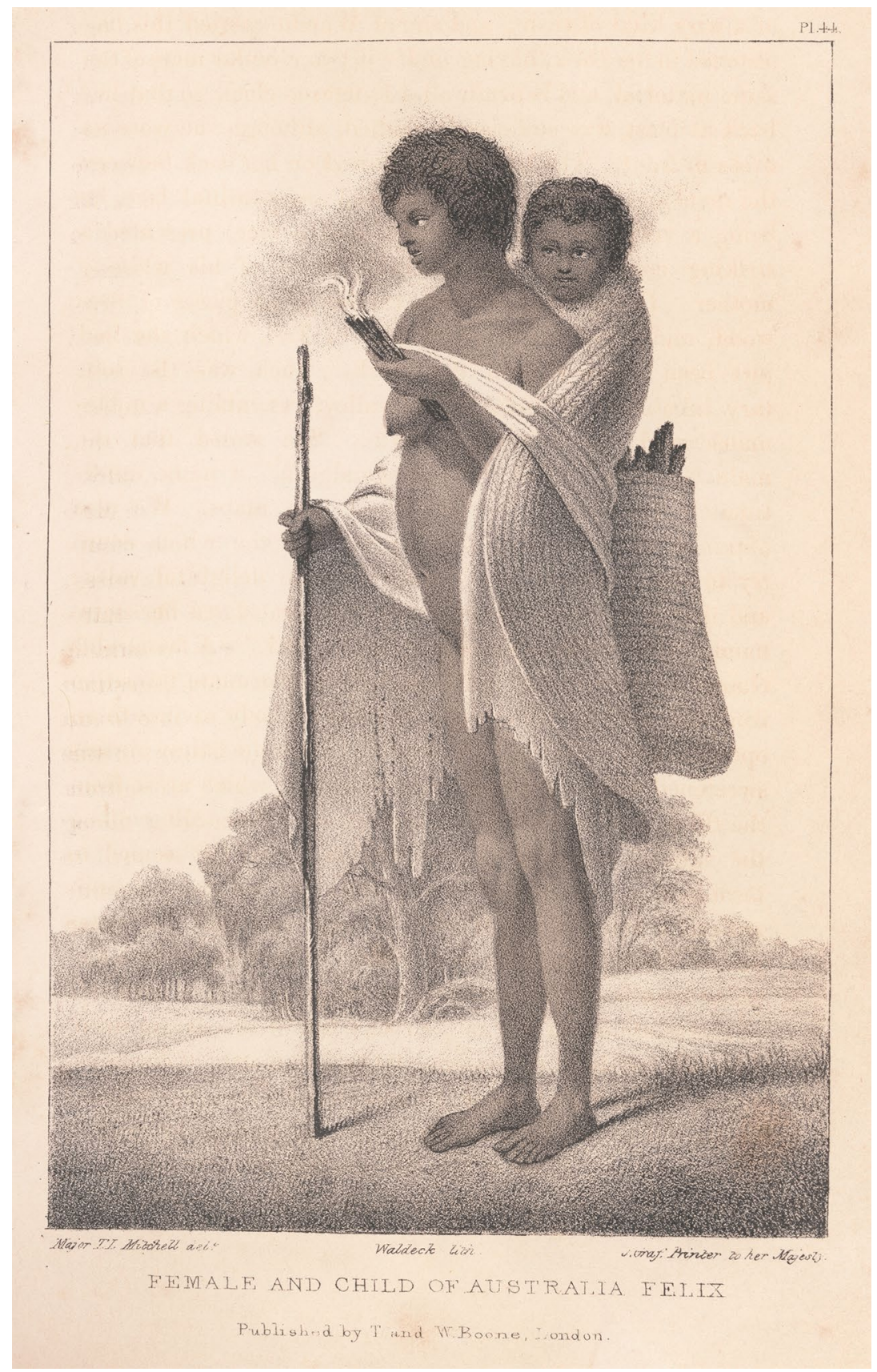

Figure 5.4: 'Female and child of Australia Felix'.

Source: Thomas Mitchell, Three Expeditions in the interior of Australia, 1839: 210-211 (Plate 44), National Library of Australia. 
The woman that the party stopped stated that the main river was called 'Temiángandgeen' and that the country to the east was similar: downs and valleys, to Mitchell's delight. When they came to a major river crossing, he thanked her by gifting her a tomahawk. The Aboriginal women interpreted for him, demonstrating its use, showing their knowledge of white people's ways and goods. Mitchell noted that 'she seemed still at a loss to conceive the meaning of a present', perhaps wondering what terms of exchange or trade had taken place. ${ }^{85}$

Finally, when the party was returning to Sydney and reached the Murrumbidgee River, Turandurey left the group. ${ }^{86}$ She reputedly left her daughter Ballandella in Mitchell's care, the mother's and daughter's faces painted white for mourning, according to Mitchell. Yet Mitchell had noted earlier that 'the mother seemed uneasy under an apprehension that I wanted to deprive her of this child', so why would she have changed her mind $?^{87}$ Turandurey may have intended that grandparents or relatives care for Ballandella. Even Mitchell acknowledged that she was under the immediate care of Kitty, rather than him. She might not have thought she was delivering her to Mitchell permanently. Stapylton described Ballandella as being 'kidnapped away' to a station 10 miles from them, raising questions about the arrangement. ${ }^{88}$ Mitchell presumed in his account that Turandurey gave her daughter to him so that she might escape the 'wretched state of slavery to which the native females are doomed' and be raised in a western way. He reached this conclusion even though Turandurey had just acted relatively independently, guiding him around her country and beyond.

Turandurey left to 'marry' King Joey of the Murrumbidgee, according to Stapylton and 'proceeds with him to her friends' ${ }^{89}$ The timing of the expedition passing through may have aligned with her own plans to travel to the area for this alliance. Perhaps this was what was discussed with the senior man before Turandurey and Ballandella joined the expedition? The gift of the expedition to her, according

85 Mitchell 1839, 10 August 1836: 211 (original emphasis).

86 Mitchell 1839, 19 September 1836: 162.

87 Mitchell 1839, 3 July 1836: 163.

88 Stapylton 1986, 7 November 1836: 235. For other theories regarding what may have happened to Turandurey and her daughter after the expedition, see Brook 1988.

89 Stapylton 1986: 235; Mitchell 1839: 335, citing Stapylton's report of 11 November, near Guy's station on the Murrumbidgee. 
to Stapylton, was a couple of leftover blankets. While this may seem small recompense for her efforts, the blankets may have proved useful to her for trading or had symbolic importance.

In his Port Davey expedition journal, Robinson wrote a revealing passage about one of the women guides:

Followed my female companion through wood sand morasses, over hills \&c for about five miles. On ascending a hill my guides descried a smoke at considerable distance rising out of a thick forest ... In a short time she called out Too gee borer [black man's fire]. Asked me if I did not see it? Said no. Took the glass and just discerned a small smoke rising out of a wood..$^{90}$

Sometimes we need guidance to see more, to assess from other perspectives, to have our attention drawn to a wisp in the distance. Trying to find out about Aboriginal women's involvement in expeditions is something like this kind of looking. They are not always obviously present, but if we look hard and do not presume they are always in hiding or absent, we may see glimpses of them.

That Aboriginal women provided crucial guidance for some expeditions is clear. Close examination of some explorer accounts reveals some indications of the range of work they did and suggests possible readings of their reasons for involvement. In the cases discussed, the Aboriginal women guides were represented as providing vital provision support, directions to water, the names of places and geographical details. Their services in translation, guarding, diplomacy, humour and care for members of the party are also evident. In the Tasmanian examples particularly, their ability as swimmers and divers was crucial to the expedition's progress. In both cases, the women's knowledge of country, observation skills and their ability to communicate and negotiate proved important to the very movement of the expedition. The women's talents in managing crosscultural relationships, etiquette and negotiation appear to have been particularly valued by these expedition leaders. It may have been the case that as women, there was less chance of their presence being interpreted as a threat by groups that the expeditions approached, especially those in dispute with each other. Harder to locate are the women's reasons for engaging in the expeditions, though some hints 
can be found. Seeing family and relations appears to have been a key motivation for many of them and the journeys may have been familiar rituals for some of them at least. Visiting country for seasonal resources and for marriage/inter-group arrangements seem likely reasons for men and women alike to have been travelling in particular areas, dovetailing with expedition timing. Gaining new experiences, knowledge and status may have been significant too. The search for the smoke and fire of their stories needs to continue.

\section{Acknowledgement}

Many thanks to Tiffany Shellam for her constructive criticism and suggestions.

\section{References}

Anderson, Ian 1995, 'Reclaiming TRU-GAN- NANER: Decolonising the symbol', in Speaking Positions: Aboriginality, Ethnicity and Gender in Australian Cultural Studies, Penny Van Toorn and David English (eds), Department of Humanities, Victoria University of Technology, Melbourne: 31-42.

2008, 'The people with no history?', in Reading Robinson: Companion Essays to George Augustus Robinson's Friendly Mission, Anna Johnson and Mitchell Rolls (eds), Quintus Publishing, Hobart.

Baker, Don 1993, 'John Piper: Conqueror of the interior', Aboriginal History 17(1): 17-37.

_ 1997, The Civilised Surveyor: Thomas Mitchell and the Australian Aborigines, Melbourne University Press, Carlton, Vic.

1998, 'Exploring with Aborigines: Thomas Mitchell and his Aboriginal guides', Aboriginal History 22: 36-50.

Batman, John 1830, John Batman's Diary, from 3 March 1830, National Library of Australia. 
Birkett, Deborah 1989, Spinsters Abroad: Victorian Lady Explorers, Basil Blackwell, Oxford.

Blunt, Alison 1994, Travel, Gender and Imperialism: Mary Kingsley and West Africa, Guilford, New York and London.

Boyce, James 2008, Van Diemen's Land, Black Inc., Melbourne.

Brock, Daniel George 1975, To the Desert with Sturt: A Diary of the 1844 Expedition, Kenneth Peake-Jones (ed.), Royal Geographical Society of Australasia, South Australian Branch, Adelaide.

Brook, Jack 1988, 'The widow and the child', Aboriginal History 12: 63-78.

Burnett, D. Graham 2000, 'Exploration, performance, alliance: Robert Schomburgk in British Guiana', Journal of Caribbean Studies 15(1\&2): 11-37.

2002, "It is impossible to make a step without the Indians": nineteenth-century geographical exploration and the Amerindians of British Guiana', Ethnohistory 49: 3-40.

Calvert, Albert 1895 The Exploration of Australia, George Philip and Son, London, Liverpool.

Carnegie, David W. 1898, Spinifex and Sand, C. Arthur Pearson, London.

Cathcart, Michael 2001, 'Exploration by land', in The Oxford Companion to Australian History, Graeme Davison, John Hirst and Stuart MacIntyre (eds), revised edition, Oxford University Press, Melbourne.

Clarke, Philip 2008, Aboriginal Plant Collectors: Botanists and Australian Aboriginal People in the Nineteenth Century, Rosenberg Publishing, Dural, NSW.

Colville, Berres Hoddle 2004, Robert Hoddle: Pioneer Surveyor 1794-1881, Research Publications, Vermont, Vic. 
Douglas, Bronwen 2009, 'In the event: Indigenous countersigns and the ethnohistory of voyaging', in Oceanic Encounters: Exchange, Desire, Violence, Margaret Jolly, Serge Tcherkezoff, Darrell Tryon (eds), ANU E Press, Canberra.

- 2014, Science, Voyages, and Encounters in Oceania, 1511-1850, Palgrave Macmillan, New York.

Driver, Felix 2012, 'Hidden histories made visible? Reflections on a geographical exhibition', Transactions of the Institute of British Geographers 38(3): 420-435.

Driver, Felix and Lowri Jones 2009, Hidden Histories of Exploration: Researching the RGS-IBG Collections, Royal Holloway, University of London in association with the Royal Geographic Society and IBG, Kensington Gore, London.

Fabian, Johannes 2000, Out of Our Minds: Reason and Madness in the Exploration of Central Africa, University of California Press, Berkeley.

Favenc, Ernest 1888, History of Australian Exploration from 1788 to 1888 compiled from state documents, private papers, and the most authentic sources, Griffith, Farran, Okeden \& Welsh, London; Turner \& Henderson, Sydney.

Grant, James 1973, The narrative of a voyage of discovery, performed in His Majesty's vessel The Lady Nelson, of sixty tons burthen, with sliding keels, in the years 1800, 1801, and 1802, to New South Wales, Libraries Board of South Australia, Adelaide.

Graves, J. W. 1876, 'Trucanini's story of herself', letter to the editor, Mercury (Hobart), 6 June 1876: 3.

Greenblatt, Stephen 1991, Marvelous Possessions: The Wonder of the New World, University of Chicago Press.

Hann, Frank Hugh 1998, Do Not Yield to Despair: Frank Hugh Hann's Exploration Diaries in the Arid Interior of Australia, 1895-1908, Mike Donaldson and Ian Elliot (comps and eds), Hesperian Press, Carlisle, WA.

Hassell, Ethel 1975, My Dusky Friends, C.W. Hassell, Fremantle, WA. 
Howitt, William 1865, The History of discovery in Australia, Tasmania and New Zealand: from the earliest date to the present day; with maps of the recent explorations, from official sources, Longman, Green, London.

Kennedy, Dane 2013, The Last Blank Spaces: Exploring Africa and Australia, Harvard University Press, Cambridge, MA.

Konishi, Shino 2008, “Wanton with plenty": Questioning ethnohistorical constructions of sexual savagery in Aboriginal societies', Australian Historical Studies 39(3): 356-372.

Leichhardt, Ludwig 1847, Journal of an expedition to the interior from Moreton Bay to Port Essington, a distance of upwards of 3000 miles, during the years 1844-1845, T. \& W. Boone, London.

Long, Charles R. 1903, Stories of Australian Exploration, Whitcombe and Tombs, Melbourne.

McGrath, Ann 1990, 'White man's looking glass', Australian Historical Studies 24(95): 189-206.

Metcalf, Alida C. 2005, Go-Betweens and the Colonization of Brazil: 1500-1600, University of Texas Press, Austin.

Miller, Linn and Patsy Cameron 2011, 'Telling Places in Country (TPIC): Historical Biographies', Australian Institute of Aboriginal and Torres Strait Islander Studies and University of Tasmania, www.utas.edu.au/telling-places-in-country/historical-context/ historical-biographies.

Mills, Sara 1991, Discourses of Difference: An analysis of women's travel writing and colonialism, Routledge, London.

Mitchell, Thomas 1838, 'Three expeditions into the interior of Eastern Australia \&c.', The Athenæum, 6 October, 571: 725-728.

1839, Three expeditions in the interior of Australia With Descriptions of the Recently Explored Region of Australia Felix and of the Present Colony of New South Wales, vol. 2, T. \& W. Boone, London. 
1848, Journal of an expedition into the tropical interior in search of a Route from Sydney to the Gulf of Carpentaria, Longman, Brown, Green and London.

Moore, George Fletcher 1836a, 'A new river discovered by the Hon. G. F. Moore, Esq on a recent excursion to the northward', The Perth Gazette and Western Australian Journal, Saturday 14 May 1836, 692-693.

1836b, 'A new river discovered by the Hon. G. F. Moore, Esq, on a recent excursion to the northwood', The Sydney Monitor, 13 August 1836, 3.

1884, Diary of ten years eventful life of an early settler in Western Australia and also a descriptive vocabulary of the Language of the Aborigines, M. Walbrook, London.

Pratt, Mary Louise 1992, Imperial Eyes: Travel Writing and Transculturation, Routledge, London.

Pridden, William 1843, Australia: Its History and Present Condition, J. Burns, London.

Reynolds, Henry 1980, The Land, the Explorers and the Aborigines, Historical Studies 19 (75): 213-226.

1990, With the White People: The Crucial Role of Aborigines in the Exploration and Development of Australia, Penguin, Ringwood, Vic.

— 1995, Fate of a Free People, Penguin, Camberwell, Vic.

- 2006, The Other Side of the Frontier: Aboriginal Resistance to the European Invasion of Australia, revised edition, UNSW Press, Sydney.

2012, A History of Tasmania, Cambridge University Press, Port Melbourne.

Robinson, George Augustus 2008, Friendly Mission: The Tasmanian Journals and Papers of George Augustus Robinson, 1829-1834, N. J. B. Plomley (ed.), Queen Victoria Museum and Art Gallery, Launceston; Quintus, Hobart. 
Rockel, Stephen J. 2000, 'Enterprising partners: Caravan women in nineteenth century Tanzania', Canadian Journal of African Studies 34(3): 748-778.

Roller, Heather F. 2010, 'Colonial collecting expeditions and the pursuit of opportunities in the Amazonian Seratao c. 1750-1800', The Americas 66(4): 435-467.

Rowan, Ellis 1898, A Flowerhunter in Australia and New Zealand, Angus \& Robertson, Sydney.

Russell, Lynette 2012, Roving Mariners: Australian Aboriginal Whalers and Sealers in the Southern Oceans, 1790-1870, State University of New York Press, Albany.

Ryan, Lyndall 1981, The Aboriginal Tasmanians, University of Queensland Press, St Lucia.

- 1986, 'Aboriginal women and agency in the process of conquest: A review of some recent work', Australian Feminist Studies $1(2): 35-43$.

2012, Tasmanian Aborigines: A History since 1803, Allen \& Unwin, Crows Nest, NSW.

Ryan, Simon 1996, The Cartographic Eye: How Explorers Saw Australia, Cambridge University Press, Cambridge.

Schaeffer, Kay 2001, 'Handkerchief diplomacy: E.J. Eyre and sexual politics on the South Australian frontier', in Colonial Frontiers: Indigenous-European Encounters in Settler Societies, Lynette Russell (ed.), Manchester University Press, Manchester: 134-50.

Shellam, Tiffany 2009, Shaking Hands on the Fringe: Negotiating the Aboriginal World at King George's Sound, UWA Publishing, Perth.

Stapylton, Granville 1986, Stapylton with Major Mitchell's Australia Felix expedition, 1836, largely from the journal of Granville William Chetwynd Staplyton, Andrews, Alan E. J. (ed.), Blubber Head Press, Hobart.

Sturt, Charles 1965 [1849], Narrative of an expedition into Central Australia, 1844, 1845, 1846, vol. 1, facsimile edition [T. \& W. Boone, London]. 
BROKERS AND BOUNDARIES

Tcherkézoff, Serge 2009, 'A reconsideration of the role of Polynesian women in early encounters with Europeans: supplement to Marshall Sahlins' voyage around the islands of history', in Oceanic Encounters: Exchange, Desire, Violence, Margaret Jolly, Serge Tcherkezoff and Darrell Tryon (eds), ANU E Press, Canberra.

Wisnicki, Adrian 2010, 'Rewriting agency: Samuel Baker, BunyoroKitara and the Egyptian slave trade', Studies in Travel Writing 14(1): 1-27. 
This text is taken from Brokers and Boundaries: Colonial Exploration in Indigenous Territory, edited by Tiffany Shellam, Maria Nugent, Shino Konishi and Allison Cadzow, published 2016 by ANU Press, The Australian National University, Canberra, Australia. 